\title{
Development of Methodology for Evaluation and Real Water Loss Reduction in Water Supply Systems in Transition Countries
}

\author{
GORAN S. ORA ̌́ANIN, Municipal Water Utility, East Sarajevo \\ DRAGANA S. RISTIĆ, REIC, Sarajevo \\ Professional paper \\ DALIBOR Z. VLAŠKI, Municipal Water Utility, East Sarajevo \\ UDC: 628.179 \\ BRANKO S. VUČIJAK, University of Sarajevo, Mechanical Engineering Faculty, Sarajevo
}

\begin{abstract}
Key strategy for water supply companies, aiming increasing their capacity and expanding the network, should be to focus on reducing water losses and non revenue water in general. Water loss reduction, after conveniently achieving initial progress, requires continuous efforts to maintain or improve the achieved level of water losses. This paper proposes a methodology developed on the basis of collected and analyzed knowledge and experience gained in water utilities in BiH and neighbouring countries. The methodology is also based on the experiences presented in the literature relating to water losses in developed countries, which are applicable or adaptable, so as affordable for the countries in transition.
\end{abstract}

Key words: methodology, real losses, district metered area, countries in transition

\section{INTRODUCTION}

Water supply companies should be efficient (operating with lowest possible effort and in optimal conditions), as well as effective (to fully provide desired services). Creation of strategy and action programme in order to reduce water loss should become inevitable integral part of management policy of a water supply company. It is significant to determine tangible and achievable goals for water loss reduction along with the implementation of a suitable methodology. Apart from conveniently applied initial efforts in this direction, water loss reduction requires further continuous efforts in order to maintain or improve reached water loss level. It is of the utmost importance for a water supply company to build and develop its own capacities in charge of water loss issues [9].

Methodology for real water loss reduction is presented with this paper. The methodology has been made in form of a summary of collected and analyzed knowledge and experiences of water supply companies in B\&H and surrounding countries. Additionally, the methodology is based on experiences presented in

Author's address: Goran Orašanin, Municipal Water Utility East Sarajevo, East Sarajevo, Nikole Tesle 53a

Paper received: 20.12.2013.

Paper accepted: 30.12.2013. literature referring to water losses in developed countries, which are applicable or adaptable, so as financially viable for transition countries. Water supply systems usually have specific methods for water loss reduction. Those experiences and knowledge are consolidated into one operative methodology. Specific suggestion of the methodology for real water loss reduction for water supply systems in transition countries follows.

\section{METHODOLOGY}

Generally, three types of measures for water loss reduction are applicable:

Short-term measures are measures for leak detection at the beginning of water loss reduction process. Those measures can be easily conducted and they give good results. Tail, unfixed leaking (reported and detected) that have been accumulated for years can be relatively quickly reduced. Conducting of those measures brings water supply company into the position that there are no visible leaks. Maintaining of such position requires additional efforts.

Mid-term measures represent organizing of the most appropriate District Metered Areas (DMA) and introducing pressure control measures. Measuring and controls in measuring area maintain attained improved position regarding water loss. Conducting of active leakage control (regularly measuring flow and 
pressure, evaluation of the water balance, detection and registration of leaks/failures and similar) reflects and enhances the improved position. Pressure control in DMAs may reduce water losses, but it can't fully eliminate them.

Long-term measures present plans encompassing replacement of pipes and connections where leaking is frequently recorded. Maintaining the database on leaks and failures within the network allows their occurrence analysis, as well as recognizing sections or connections (where large losses occur) within the water supply system characterized with frequent leakages.

Water loss reduction, along with fulfilling all three aforementioned measures, can be achieved by implementing the following steps (Figure 1):

Step 1 Organization of the water losses control department

In order to achieve efficient management of water supply systems, especially regarding water loss aspect, it is inevitable and crucial to reorganize water supply companies. Determination of employees' number and structure, dealing with water loss issues in water supply systems, represents an important precondition for water loss reduction in water supply companies. This means that firstly, water supply companies should have a special unit for water loss control, needed for continuous following up and maintaining of water losses at acceptable level [9].

In order to organize Water loss control Service it is necessary to provide technical and material preconditions for successful business running (vehicle, measurement devices, sound leak detection equipment, personal computers and other IT, and other equipment) as well as adequate working space. Water loss control equipment ${ }^{1}$ necessary for any water supply company depends on the network condition and quantity of losses in the system, as well as on financial and human resources of the company.

\section{Step 2 Water balance}

Periodical water balance evaluation should be conducted for the entire system, due to the fact that employees should have a sense how much water loss can be expected in metering areas. Water losses should be presented as liter/connection/day. It should be

\footnotetext{
${ }^{1}$ Here it is necessary to emphasize that equipment could be purchased, via water associations, for more than one water supply company, or that equipment could be periodically rented from some other water supply company. In case of small water supply companies, it is recommended that few water supply companies, geographically near, purchase equipment and organize one service that would cover working activities for each and every included company.
}

calculated in accordance to IWA recommendations and based on ILI (Infrastructure Leakage Index) as an excellence indicator pointing at changes in efficiency category $[2,5,11]$.

Quantity of Non Revenue Water (NRW) is being determined in a way that water audit is being conducted and results are shown in the water balance. Water balance is based on measuring or quantitative estimations of produced water, exported, imported, used and lost water. International Water Association (IWA) recommends tabular review of water balance which each and every water supply company should have in order to start activities regarding water loss reduction. Water balance table provides indicators and quantity of the water used and water lost in any way.

Evaluation of the water balance ${ }^{2}$ has a goal to follow up and identify each and every water balance component in a specific time period. Based on calculation method, all consumption components as well as losses are being identified in one standardized fo$\mathrm{rm}$ in this water balance. Clearly defined water balance represents a first step in the process of evaluation of non revenue water, water losses and leakage management in water supply systems [4].

Regarding evaluation of the water balance, it is important to have in mind the fact that accuracy of data on water loss quantity depends on accuracy and data quality used during the process of evaluation. Thus, reliable measuring of all inputs, as well as outputs, represents a basic demand. Reliable data on water pipe length, number of connections and other represent second demand. However, in transition countries, it is relatively unusual for a water supply company to have exact data on water quantity entering water supply system. Thus, those evaluations of the water balance are considered as approximate ones, due to the difficulties to estimate all components accurately. Irrespective of those difficulties in estimation of water balance components, it is always necessary to calculate water balance. (DMA)

Step 3 Determinations of District Metered Areas

DMA implementation enables dividing of the whole water supply system into smaller and limited zones (sub-systems) that can be easily controlled. International Water Association roughly recommends DMA from 500 to 3000 connections. However, IWA

\footnotetext{
${ }^{2}$ www.waterloss.com.ba is a web page made in 2012. by Mr. Djevad Koldzo, expert for Non Revenue Water. Apart from other things, two software tools for evaluation of water balance as well as for failure record on water supply network can be found here.
} 
also states that hydraulic, practical and economic factors set size of district metered area DMA [8], what leads to the conclusion that within one water supply system a DMA would differ from the other one in number of connections.

Procedure is as follows: firstly, district metering areas in the area of water supply system are being determined; first area is being selected and measuring is being performed within it; then accurate water balance is being calculated, failures are being identified and fixed. Upon finishing of all aforementioned, the procedure is being performed for the next DMA. Testing in metering area should be conducted in three steps [3]: (i) first testing represents preliminary determination of condition (evaluation of water balance) and narrowing down of the area where leakage appears (night measuring method); (ii) second testing represents direct testing of the failure/leak place or location (sound leak detection and leakage spot location) and (iii) Third testing is being performed upon repairing of defined leakage spots in order to check effects of repair to the water balance. The procedure is iterative until achieving sufficient results, that is, new water balance is being compared to previous

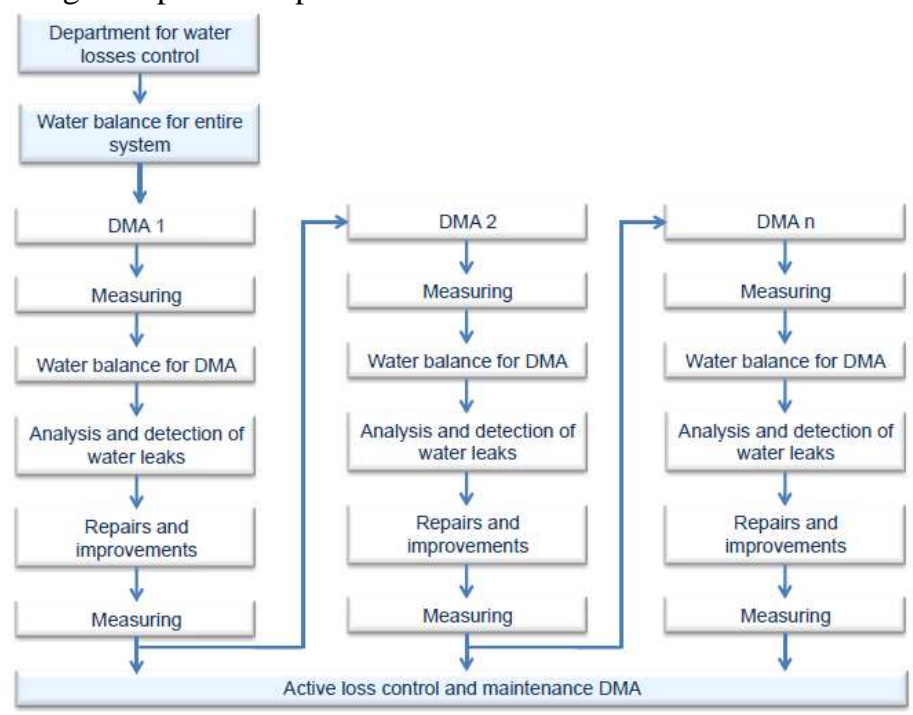

Figure 1 - Schematic overview of the methodology

The following chapter demonstrates the results achieved for DMA of East Sarajevo water supply system, where previously mentioned procedure has been undertaken. Established department for water losses control has performed preliminary measures in order to determine condition, that is, Service has determined water balance for the clearly defined metering area. Following activities have been performed: at first, failures have been detected, closely located and then repaired; pressure has been regulated; repeated measuring has been performed in order to water balance and improvements are being determined. If the results are not satisfactory, the procedure should be repeated starting from night measuring method.

Testing procedure should be conducted at all DMAs in water supply system.

Step 4 Active loss control and system maintenance

Upon establishing of all DMAs in water supply system, active loss control represents a very significant part of process of maintaining of attained improvement level [1]. Based on field work, detecting of invisible leakages and failure record improvement measures for certain measuring areas are being defined. There can be a case that for a certain measuring areas in a certain time period there is no need to conduct additional measures (there are no frequent failures, acceptable pressure level in DMA, that is, DMA losses are at acceptable level). However, there can also be a case that in some metering areas pressure should be controlled $[6,7,10]$ as well as reservoir leaking or pipe-lines and connections should be replaced.

determine condition and repair effects. Achieved results are presented in this paper, and were followed by active loss control and system maintaining in order to maintain attained level of improvement.

\section{EXAMPLE OF EAST SARAJEVO WATER SUPPLY SYSTEM DMA}

District Metered Area (DMA) selected for testing of this methodology, represents a closed area with one water entrance to the system, that is, looking from the hydraulic aspect, water supplement is closed- 
water towards settlement goes in one direction and does not leave that settlement. Measuring area is being supplied by water via pump station, that is, water is directly being pumped up into the network. This represents an interested fact regarding measuring area analyzing, especially regarding the aspect of real water losses. Pump station is located at altitude 550,5 $\mathrm{m}$. Pressure at the entrance to the pump station varies in range from 2,8 to 3,5 bars. Pump station is set to pressure from 5,5 to 7,5 bars. Ultimate and critical points are at $574 \mathrm{~m}$ altitude (measuring spot - MM 2) and $570 \mathrm{~m}$ altitude (measuring spot - MM 3).

\section{Figure 2 - District meter area}

Water supply network of this measuring area, along with data received by performing of testing at the terrain during the process of measuring area determination, is given in Figure 2. During the process of terrain research, following data have been collected: population number-about 700; number of connections-188 (households-177 and legal subjects11): network lenght-3.063 m (PE 63, PE 90, PE 110, and PE 160).

Based on network characteristics, critical points and possibility to set flow meter, three measuring areas have been determined. At one measuring area (at pump station) pressure and flow have been measured, while on other two spots only pressure has been measured. Measures have been conducted into two phases per 7 days. During the first measuring, average water quantity that entered into entire water supply system was $108,83 \mathrm{l} / \mathrm{s}$. Based on indicators given by first measuring, three failures have been located and repaired, so the pressure at pump station was reduced for 0,5 bars. Upon conducting of those measures second measuring has been performed. During the second measuring, average water quantity that entered water supply system was $115,06 \mathrm{l} / \mathrm{s}$.

\subsection{Measurements analysis}

During flow meter setting, reading of values on water meters has been performed in district meter area. Additionally, 7 days later, values on water meters have been read in that district meter area. That very day measuring data have been downloaded. Values recorded at water metres for 186 water metres and two evaluated lump households were $578 \mathrm{~m}^{3}$. Results showed that average flow in 7 days time period of measuring was $1,5 \mathrm{l} / \mathrm{s}$ (Table 1 ).

The same procedure has been conducted during the second measuring. Figure 3 shows results of flow measuring during the first and second measuring. Results showed that average flow in 7 days time period of measuring was $1,54 \mathrm{l} / \mathrm{s}$ (Table 1 ).

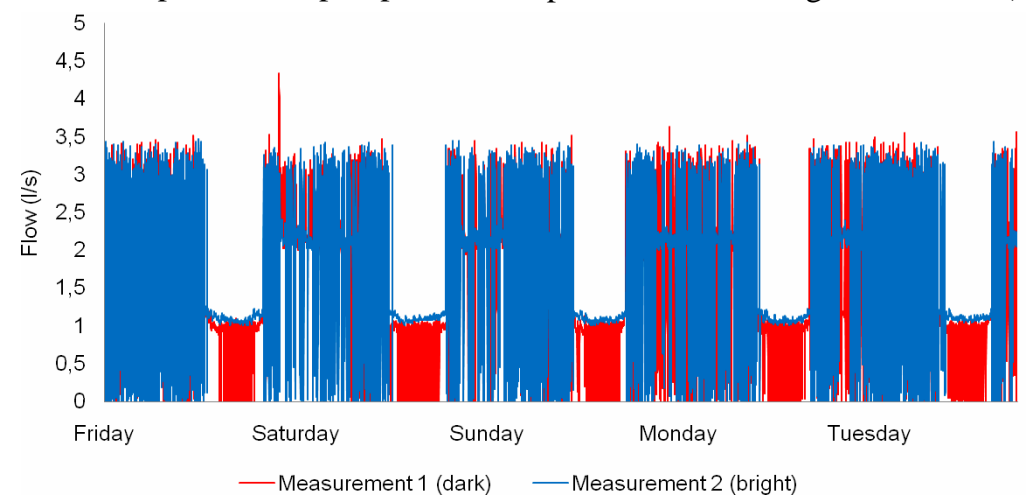

Figure 3 - Comparison chart of measurements of flow 
Table 1 represents a comparison of average flow for days during first and second measuring.

Flow increase in the second measuring was caused by significantly lower temperatures in comparison to temperatures during the first measuring. Recorded flow of $1,51 / \mathrm{s}$ during the first measuring is a result of smaller failures in the system as well as result of higher pressure than it was during the second measuring. Flow of 1,54 1/s at temperatures which reached $-20{ }^{\circ} \mathrm{C}$ during the night represented increase of consumption due to the fear of population that water in household installations could froze. This conclusion is supported by the fact that minimal night flow in those days is not equal to zero (as it was the case during the first measuring) but it is equal or higher than $1 \mathrm{l} / \mathrm{s}$. However, during the day flow equal to zero appears what points to the fact that there are no bigger failures in the system.

Table 1. Comparison of average flow

\begin{tabular}{|l|l|l|l|l|l|l|l|l|}
\cline { 2 - 9 } \multicolumn{1}{c|}{} & 1 & 2 & 3 & 4 & 5 & 6 & 7 & Average \\
\hline Measuring 1 & 1,52 & 1,34 & 1,49 & 1,46 & 1,48 & 1,65 & 1,53 & 1,50 \\
\hline Measuring 2 & 1,58 & 1,56 & 1,49 & 1,52 & 1,45 & 1,62 & 1,58 & 1,54 \\
\hline
\end{tabular}

Figure 4 shows comparative results of pressure measuring, minimal entrance pressure was decreased measuring during the first and second measuring at the entrance to the system. Upon finishing first from 5,5 bars to 4,76 , and maximal pressure was decreased from 7,5 bars to 6,87 bars.

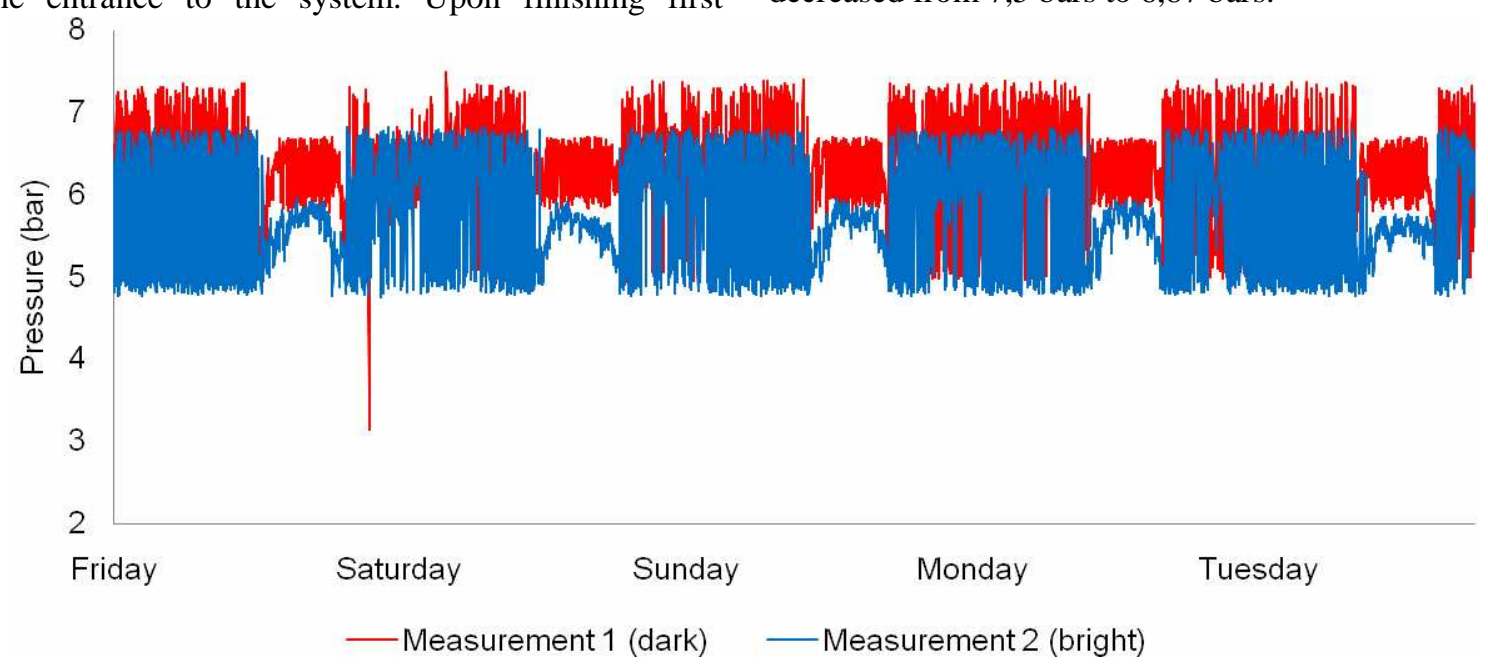

Figure 4 - Comparison chart of measurements of pressure at the measuring spot 1

Figure 5 shows comparative results of pressure measuring at measure spot 2 (MM 2). By reducing of pressure at entrance to the system, minimal pressure

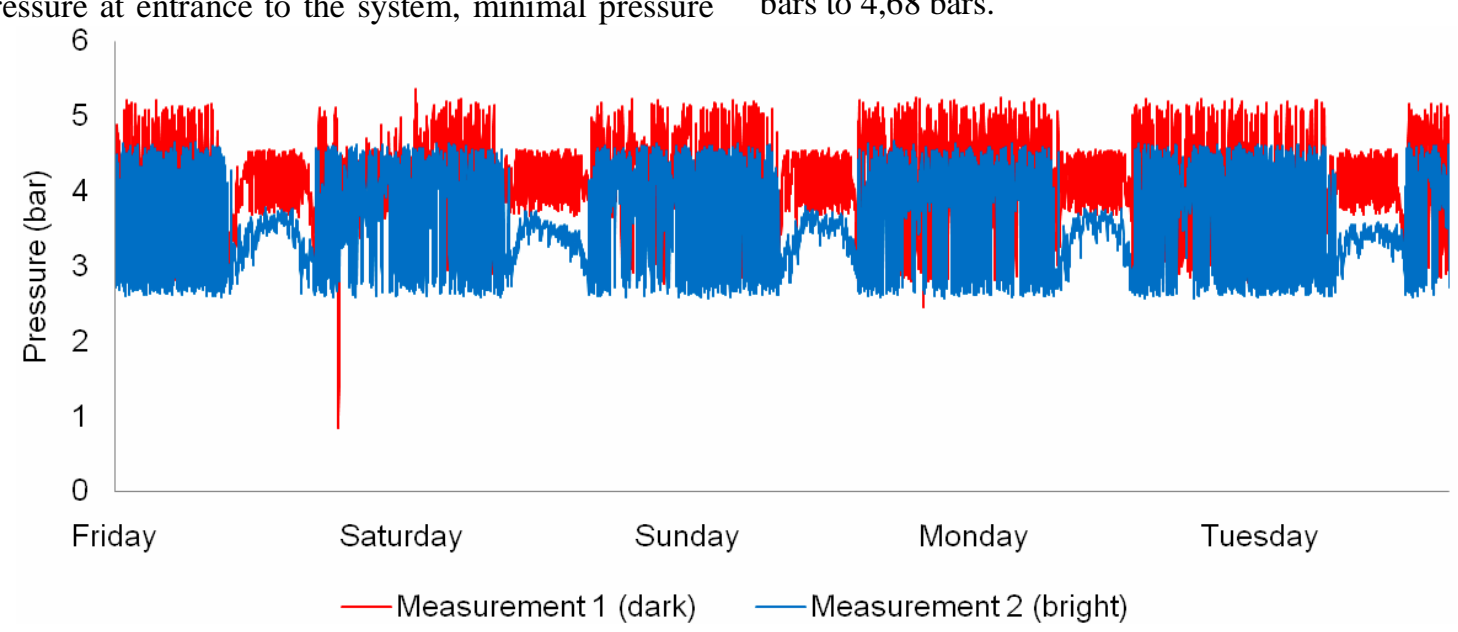

Figure 5 - Comparison chart of measurements of pressure at the measuring spot 2 
Figure 6 shows comparative results of pressure measuring at measure spot 3 (MM 3).By reducing of pressure at entrance to the system, minimal pressure at measure spot 3 was reduced from 2,3 bars to 1,94 bars, while maximal pressure was reduced from 5,08 bars to 4,54 bars.

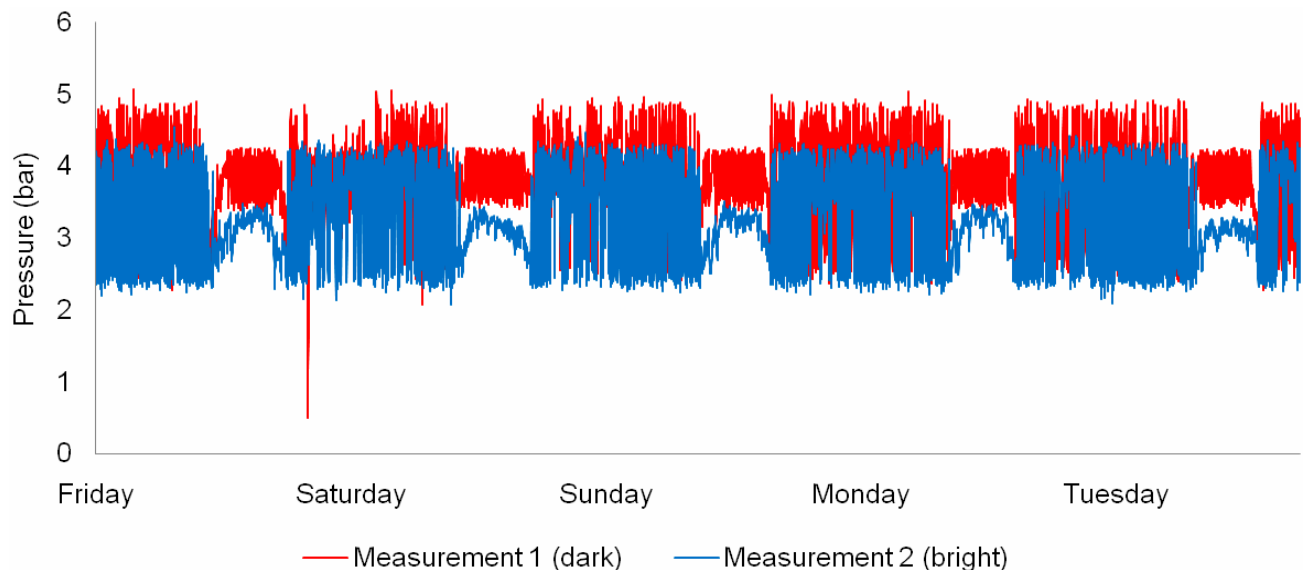

Figure 6 - Comparison chart of measurements of pressure at the measuring spot 3

Table 2 shows average pressure for all 3 measure spots during both measuring.

The table clearly shows that average pressures in second measuring are lesser for 0,5 bars. This is

Table 2. Comparison of average pressure result of lower pressure at DMA entrance (pump station). Total average pressure in the system is lower for 0,55 bars, that is, it is reduced from 4,68 to 4,13 bars.

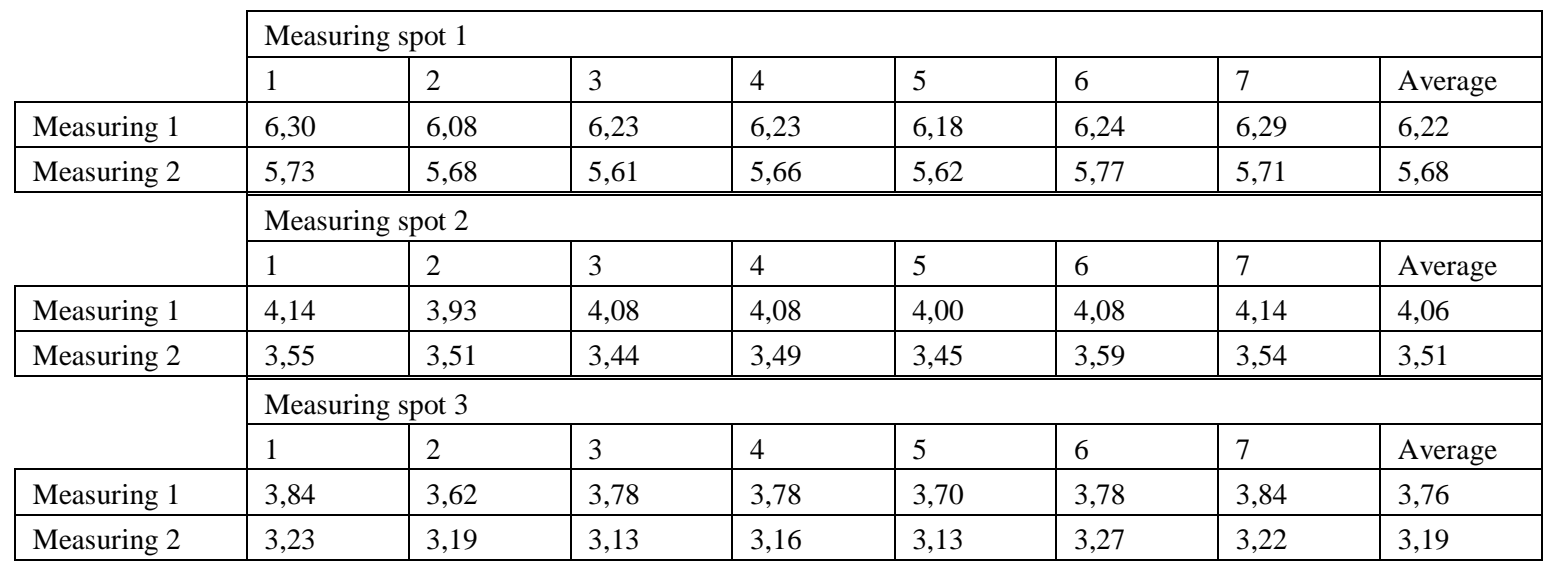

In line with IWA recommendations, water balance in DMA is calculated after first and second measuring.

Based on network length (3.603.m), average pressure in system during the course of the first and second measuring (4,68 bar and 4,13 bar), number of connections (188) and average distance of water me- ters in private ownership (5m), Current Annual Real Losses (CARL), Unavoidable Annual Real Losses (UARL) and ILI (Infrastructure leakage Index) indicators are being calculated.

Connection density per network kilometre is $\mathbf{5 2}$ connections, so the indicators are presented as liter/connection/day (Table 3).

Table 3. Comparison of system's condition indicators

\begin{tabular}{|l|l|l|l|l|l|}
\cline { 2 - 6 } \multicolumn{1}{c|}{} & $\begin{array}{l}\text { CARL } \\
\text { (liter/connection/day) }\end{array}$ & $\begin{array}{l}\text { UARL } \\
\text { (liter/connection/day) }\end{array}$ & $\begin{array}{l}\text { Improvement potential } \\
\text { (liter/connection/day) }\end{array}$ & ILI & $\begin{array}{l}\text { NRW } \\
(\%)\end{array}$ \\
\hline Measuring 1 & 218,2 & 53,6 & 164,6 & 4,1 & 36,1 \\
\hline Measuring 2 & 188,22 & 47,3 & 104,92 & 4 & 31 \\
\hline Result & $-13,7 \%$ & $-11,7 \%$ & $-36,3 \%$ & $-2,4 \%$ & $-5,1$ \\
\hline
\end{tabular}


Table 3 shows comparison of system's condition indicators between the two measuring. Non-Revenue Water (NRW) percentage is lower for 5,1 than it was during the second measuring. Infrastructure Leakage Index (ILI) indicator is decreased for 0,1 . Due to the pressure decrease, Unavoidable Annual Real Losses (UARL) are lower for 6,3 liter/connection/day. Repair of failures, pressure decrease and increased consumption caused Current Annual Real Losses (CARL) to be lower for 29,98 liter/connection/day, while improvement potential (difference between CARL and UARL) is lower for 59,68 litre/connection/day. By CARL water decrease, economic or financial benefits are the following ones: i) 205,72 euro/annually if using the marginal water production cost (estimated cost of water production is 0,10 Euros $/ \mathrm{m} 3$ ); ii) 1542,92 euro/annually if using the water supply tariff and sewage tariff (estimated tariff for water supply and sewage is 0,75 Euros $/ \mathrm{m} 3$ ).

\section{CONCLUSION}

In the frame of proposed methodology, described in this paper, step by step approach has been developed which should be based on measuring and dividing of water supply system to smaller sub-systems (DMAs). Implementation of this methodology to any water supply system can be defined based on a procedure, which is based on sequence of actions through the following steps:

- Organization of department for water losses control (delegation of employees in charge of this activity);

- Water balance evaluation for water supply system (rising of consciousness what can be expected to occur in water supply system regarding water losses);

- Determination of District Metered Areas and measuring in those areas (determination of actual condition in sub-systems);

- Repair of failures, improvement measures and measuring (determination of improvement measures success); and

- Active loss control and infrastructure maintaining in district meter areas and entire system (maintaining of attained level of decreased real water losses and improvement activities).

Results demonstrated in this paper can be also achieved in other district metered areas, at the same time thus proving that applied procedure for water loss decrease in one district meter area can be applied to the entire water supply system.

\section{REFERENCES}

[1] Farley M., Liemberger R., (2005), Developing a non-revenue water reduction strategy: planning and implementing the strategy, Water Science and Technology: Water Supply Vol. 5 No. 1 pp. 41-50, IWA Publishing.

[2] Hamilton S., Mckenzie R., (2006), Seago C., A Review of Performance Indicators for Real Losses from Water Supply Systems, UK house of commons report, Juli.

[3] Koldžo Đ., (2004), Priručnik za efikasno mjerenje i otkrivanje gubitaka u vodovodnim sistemima, Institut za hidrotehniku Građevinskog fakulteta u Sarajevu, Sarajevo.

[4] Lambert A., Hirner W., (2000), IWA BLUE PAGES, Losses from Water Supply Systems: Standard Terminology and Recommended Performance Measures, London.

[5] Lambert A., Mckenzie R., (2002), Practical Experience in using the Infrastructure Leakage Index. IWA Conference "Leakage Management - A Practical Approach", Conference Proceedings, Cyprus.

[6] McKenzie R., Wegelin W. (2009), Implementation of Pressure Management in Municipal Water Supply Systems. IWA pres paper 0309.

[7] McKenzie R., Wegelin W. (2010), Pressure Management in South Africa. Proceedings of the WISA Conference, Durban, South Africa.

[8] Morrison J., Tooms S., Rogers D., (2007), District Metered Areas, Guidance Notes, International Water Association.

[9] Orašanin G., Vlaški D., Vučijak B., (2012), Improving the water utilities' organizational structure in transition countres as a precondition to reduce water losses, Tehnika Vol. 67 No. 6, pp. 10371042.

[10] Thornton, J. (2003), Managing leakage by managing pressure: a practical approach. Water 21 , No. 43-44.

[11] Winarni W., (2009), Infrastructure Leakage Index (ILI) as Water Losses Indicator, Civil Engineering Dimension, Vol. 11, No 2, pp 126 - 134. 


\section{REZIME}

\section{RAZVOJ METODOLOGIJE ZA EVALUACIJU I SMANJENJE STVARNIH GUBITAKA VODE ZA VODOVODNE SISTEME ZEMALJA U TRANZICIJI}

Vodovodna preduzeća kao ključnu strategiju za povećanje kapaciteta i širenja mreže trebaju odabrati usmjerenje ka smanjenju gubitaka vode $i$ uopšte na smanjenju neprihodovne vode. Smanjenje gubitaka vode nakon početnog napretka zahtijeva $i$ dalje napore na održavanju dostignutog nivoa gubitaka vode. $U$ radu je predložena metodologija koja je nastala kao rezime prikupljenih $i$ analiziranih znanja i iskustava iz vodovodnih preduzeća u BiH i zemalja u okruženju. Metodologija se, takođe, bazira na iskustvima prikazanim u literaturi koja se odnose na gubitke vode u razvijenim zemljama, a koja je primjenljiva ili prilagodljiva, kao i finansijski prihvatljiva za zemlje u tranziciji.

Ključne riječi: metodologija, stvarni gubici vode, ograničena mjerna oblast, zemlje u tranziciji 